\title{
Antimicrobial effect of toothbrush with light emitting diode on dental biofilm attached to zirconia surface: an in vitro study
}

\author{
Jong Hew Park', Yong-Gun Kim², Heung-Sik Um¹, Si Young Lee 3 , Jae-Kwan Lee ${ }^{1 *}$, Beom-Seok Chang ${ }^{1 *}$ \\ 'Department of Periodontology and Research Institute of Oral Sciences, Gangneung-Wonju National University College of \\ Dentistry, Gangneung, Republic of Korea \\ ${ }^{2}$ Department of Periodontology, Kyungpook National University School of Dentistry, Daegu, Republic of Korea \\ ${ }^{3}$ Department of Microbiology and Immunology and Research Institute of Oral Sciences, Gangneung-Wonju National University \\ College of Dentistry, Gangneung, Republic of Korea
}

Purpose: The purpose of this study was to evaluate the antimicrobial effects of a toothbrush with light-emitting diodes (LEDs) on periodontitis-associated dental biofilm attached to a zirconia surface by static and dynamic methods. Materials and Methods: Zirconia disks (12 mm diameter, $2.5 \mathrm{~mm}$ thickness) were inserted into a 24-well plate (static method) or inside a Center for Disease Control and Prevention (CDC) biofilm reactor (dynamic method) to form dental biofilms using Streptococcus gordonii and Fusobacterium nucleatum. The disks with biofilm were subdivided into five treatment groups-control, commercial photodynamic therapy (PDT), toothbrush alone (B), brush with LED (BL), and brush with LED+erythrosine (BLE). After treatment, the disks were agitated to detach the bacteria, and the resulting solutions were spread directly on selective agar. The number of viable bacteria and percentage of bacterial reduction were determined from colony counts. Scanning electron microscopy (SEM) was performed to visualize alterations in bacterial morphology. Results: No significant difference in biofilm formation was observed between dynamic and static methods. A significant difference was observed in the number of viable bacteria between the control and all experimental groups $(P<0.05)$. The percentage of bacterial reduction in the BLE group was significantly higher than in the other treated groups $(P$ $<0.05)$. SEM revealed damaged bacterial cell walls in the PDT, BL, and BLE groups, but intact cell walls in the control and B groups. Conclusion: The findings suggest that an LED toothbrush with erythrosine is more effective than other treatments in reducing the viability of periodontitis-associated bacteria attached to zirconia in vitro. (J Dent Rehabil Appl Sci 2019;35(3):160-9)

Key words: biofilm; erythrosine; peri-implant disease; photochemotherapy; toothbrushing

\section{Introduction}

Peri-implantitis is an infectious disease caused by bacteria from dental biofilms. ${ }^{1}$ A history of periodontitis, cigarette smoking, poor oral hygiene, and

\footnotetext{
*Correspondence to: Jae-Kwan Lee

Professor, Department of Periodontology and Research Institute of Oral Sciences,

Gangneung-Wonju National University College of Dentistry,

7 Jukheon-gil, Gangneung, 25457, Republic of Korea

Tel: +82-33-640-3199, Fax: +82-33-640-3103, E-mail: periojk@gwnu.ac.kr

*Correspondence to: Beom-Seok Chang

Professor, Department of Periodontology and Research Institute of Oral Sciences,

Gangneung-Wonju National University College of Dentistry,

7 Jukheon-gil, Gangneung, 25457, Republic of Korea

Tel: +82-33-640-3188, Fax: +82-33-640-3113, E-mail: dentist@gwnu.ac.kr

Received: August 27, 2019/Last Revision: August 31, 2019/Accepted: September

1,2019
}

lack of periodic supportive periodontal therapy are considered risk factors for peri-implantitis. ${ }^{2-4}$ The composition of biofilm microorganisms around the implant is similar to that observed in periodontitis, which may increase the risk of peri-implantitis in patients with active periodontal disease. ${ }^{5}$ Dental biofilm formation begins with the pellicle from saliva that covers the surface of the tooth within a few minutes

CopyrightC 2019 The Korean Academy of Stomatognathic Function and Occlusion. (c) It is identical to Creative Commons Non-Commercial License. 
of mechanical cleansing. Early colonizers including Streptococcus and Actinomyces spp. directly adhere to the pellicle. ${ }^{6,7}$ As inflammation progresses, some gramnegative bacteria present in the biofilm, including Fusobacterium nucleatum, play an important role by linking several periodontal pathogens, such as Porphyromonas gingivalis, Treponema denticola, and Tannerella forsythia, to form the "red complex"., A strong association has been observed between the "red complex" and occurrence of peri-implantitis. ${ }^{10}$ Thus, early intervention of peri-implant mucositis and cleansing of early bacterial colonization play important roles in the control of peri-implant disease.

Periodontal disease begins with plaque deposition in the gingival crevice; thus, peri-implant disease progression is associated with plaque deposition on the implant abutment surface and surrounding crevice of the peri-implant area. Therefore, the properties and surface modification of the implant abutment material may affect peri-implant conditions. Zirconium oxide (zirconia) has been recently used as an implant abutment for aesthetic purposes, as its color is similar to that of natural teeth. ${ }^{11,12}$ In addition, zirconia has a high-loading capacity, and excellent corrosion resistance and biocompatibility, indicative of its suitability as an implant abutment material. ${ }^{13,14}$ Nascimento et al. ${ }^{15}$ revealed no significant difference between the bacterial species attached to zirconia and titanium disks but observed a significant difference in the degree of colonization; titanium disks presented higher counts of bacteria than zirconia disks. Another study observed no significant differences between the species and the amount of bacteria present on zirconia and titanium surfaces. ${ }^{16}$ These results indicate that zirconia, like titanium, is vulnerable to periodontal bacteria in the mouth, and that surface cleaning of zirconia abutments may be significant in the prevention of peri-implant disease.

Treatment studies of peri-implant disease have focused on the cleansing of the implant and abutment material surfaces. Limited accessibility around the implant and abutment may complicate the removal of the bacterial load with mere mechanical debridement. ${ }^{17}$ Also, mechanical devices are known to damage the surfaces of implants and abutments. Al- though local and systemic antibiotics have been used to manage this problem, these bacteria have shown resistance to antibiotics. Several methods have been proposed for cleaning the surface of implants, but none of these methods have demonstrated superiority over other methods. ${ }^{18}$

Photodynamic therapy (PDT) is a newly proposed method for treating periodontitis and peri-implant diseases that applies a combination of light, photosensitizers, and oxygen. ${ }^{19}$ Irradiation with light of a specific wavelength results in the transition of the photosensitizer from a low energy state to a singlet state. Clinical plaque disclosing agent erythrosine is a potential photosensitizer for the PDT of oral plaque biofilms. ${ }^{20}$ This process produces reactive oxygen species such as free radicals and singlet oxygen, which are extremely toxic to bacteria. ${ }^{21}$ Bassetti et al. $^{22}$ compared the effects of PDT and local drug delivery on the treatment of peri-implant disease and found that PDT could essentially replace local drug delivery. Recently, adjunctive PDT with mechanical debridement in the management of peri-implantitis has been suggested to improve periodontal conditions. ${ }^{23,24}$ We recently evaluated the antibacterial effect of a newly devised toothbrush with light-emitting diodes (LEDs) on Porphyromonas gingivalis attached to sandblasted and acid-etched (SLA) titanium surfaces. The antibacterial effect of the LED toothbrush with erythrosine was better than that of a commercial PDT kit. ${ }^{25}$

Researchers have used an in vitro periodontitisassociated dental biofilm model for evaluating the antimicrobial effects of various treatment options for peri-implant disease because in vivo periodontitisassociated biofilm can be altered by host problems and many ethical considerations. ${ }^{26}$ Frankline et al. ${ }^{27}$ suggested that an in vitro dental biofilm model using a Center for Disease Control and Prevention (CDC) biofilm reactor (dynamic method) can create an environment similar to the saliva and gingival crevicular fluid in the oral cavity. However, few studies have reported the efficacy of an LED toothbrush on dental biofilm attached to a zirconia surface by CDC biofilm reactor. Therefore, the present study aimed to evaluate the antimicrobial effects of the LED 
toothbrush on periodontitis-associated dental biofilm attached to a zirconia surface prepared by static and dynamic methods.

\section{Materials and methods}

\section{Zirconia disk preparation}

Zirconia disks (HASS Corporation, Gangneung, Korea) measuring $12 \mathrm{~mm}$ in diameter and $2.5 \mathrm{~mm}$ in thickness were manufactured. One side of the zirconia disk was covered with a putty-type hydrophilic vinyl polysiloxane material (Eli-dent Group S.P.A., Fiorentino, Italy) so that bacteria attach to only one side of the disks. The disks were soaked in $70 \%$ ethanol for $60 \mathrm{~s}$ and sterilized in an autoclave. The disks were then placed in the wells of a 24-well polystyrene cell culture plate (SPL Life Sciences Co., Ltd., Pocheon, Korea) with $2 \mathrm{~mL}$ of artificial saliva (Kolmar Korea Co., Ltd., Sejong, Korea), and the plate was incubated at $37^{\circ} \mathrm{C}$ with gentle shaking for $4 \mathrm{~h}$ to form acquired pellicles.

\section{Bacterial strain and culture conditions}

The two strains of periodontitis-associated bacteria used in this study were Streptococcus gordonii DL1 and F. nucleatum ATCC 23726. All bacteria were grown in trypticase soy broth (Becton, Dickinson and Company, Sparks, USA) supplemented with $1 \mathrm{mg} / \mathrm{mL}$ yeast extract (Becton, Dickinson and Company, (Becton, Dickinson and Company, Sparks, USA), $5 \mu \mathrm{g} /$ $\mathrm{mL}$ hemin, and $1 \mu \mathrm{g} / \mathrm{mL}$ menadione. $S$. gordonii and F. nucleatum were incubated in an anaerobic chamber $\left(90 \% \mathrm{~N}_{2}, 5 \% \mathrm{CO}_{2}\right.$, and $5 \% \mathrm{H}_{2}$; Sheldon Manufacturing Inc., Cornelius, USA) at $37^{\circ} \mathrm{C}$.

\section{Static method}

For biofilm formation using the static method, 25 $\mu \mathrm{L}$ of $S$. gordonii bacterial suspension $\left(1 \times 10^{9} \mathrm{CFU} /\right.$ $\mathrm{mL}$ ) in $2 \mathrm{~mL}$ trypticase soy broth containing $5 \mu \mathrm{g} /$ $\mathrm{mL}$ of hemin and $1 \mu \mathrm{g} / \mathrm{mL}$ of menadione was inoculated in 24-well cell culture plates (Corning Inc., New York, USA) in the presence of the zirconia disks. The plates were incubated for $24 \mathrm{~h}$ at $37^{\circ} \mathrm{C}$ in an anaerobic environment. After $24 \mathrm{~h}$, the bacterial suspension was removed. In addition, $25 \mu \mathrm{L}$ of $F$. $n u$ cleatum bacterial suspension $\left(1 \times 10^{9} \mathrm{CFU} / \mathrm{mL}\right)$ in 2 $\mathrm{mL}$ trypticase soy broth supplemented with $5 \mu \mathrm{g} / \mathrm{mL}$ hemin, and $1 \mu \mathrm{g} / \mathrm{mL}$ menadione was inoculated in the same 24-well cell culture plates and incubated for 5 days at $37^{\circ} \mathrm{C}$ to induce the formation of a multispecies biofilm. Fresh medium was added for 3 days.

\section{Dynamic method}

For biofilm formation using the dynamic method, disks were mounted on polypropylene coupon holders and placed in a CDC biofilm reactor (BioSurface Technologies Corporation, Bozeman, USA). The reactor was filled with $350 \mathrm{~mL}$ of $S$. gordonii suspension at a concentration similar to that used in the static method described above. After $24 \mathrm{~h}$, the S. gordonii suspension was removed and $350 \mathrm{~mL}$ of F. nucleatum suspension was added at concentration similar to that used in the static method described above. The culture was incubated for 5 days at $37^{\circ} \mathrm{C}$ to induce the formation of a multi-species biofilm. Fresh medium was added for 3 days.

\section{Instrumentation and quantitative evaluation of bacterial removal}

After 5 days of incubation, the zirconia disks with multi-species biofilms formed using the dynamic and static methods were divided into five groups, comprising eight disks each (Table 1): negative control;

Table 1. Treatment protocol

\begin{tabular}{ccc}
\hline Group & Treatment & $\mathrm{N}$ \\
\hline Control & $\begin{array}{c}\text { No treatment } \\
\text { Methylene blue }(60 \mathrm{~s}), \\
\text { PDT }\end{array}$ & 8 \\
B & Brush $(60 \mathrm{~s})$ & 8 \\
BL & Brush with LED $(60 \mathrm{~s})$ & 8 \\
BLE & $\begin{array}{c}\text { Erythrosine }(60 \mathrm{~s}), \\
\text { brush with LED }(60 \mathrm{~s})\end{array}$ & 8 \\
\hline
\end{tabular}

PDT, photodynamic therapy; B, brush alone; BL, brushing with a LED light; BLE, brushing with a LED light and erythrosine. 
commercial photodynamic therapy (PDT; Periowave system, Ondine Biomedical Inc., Vancouver, Canada) as positive control; brushing with toothbrush (B; Smart E-care, AinA Co., Ltd., Daegu, South Korea) only; brushing with an LED light (BL): and brushing with an LED light and erythrosine (BLE). The LED light comprised one red LED (630 nm, $44 \mathrm{~mW})$, two blue LEDs (465 nm, $64 \mathrm{~mW}$ ), and one white LED $(550 \mathrm{~nm}, 64 \mathrm{~mW})$. The disks from the PDT group were placed in methylene blue $(1 \mathrm{~mL}, 100 \mu \mathrm{g} / \mathrm{mL})$ for $60 \mathrm{~s}$, followed by irradiation $(670 \mathrm{~nm}, 160 \mathrm{~mW})$ with the diode laser for $60 \mathrm{~s}$. The disks from the $\mathrm{B}$ group were only brushed for $60 \mathrm{~s}$. A brush attached electric toothbrush was applied by a constant speed and direction for desirable experimental results. The disks from the BL group were brushed with an LED light for $60 \mathrm{~s}$. The disks from the BLE group were placed in erythrosine $(1 \mathrm{~mL}, 22 \mu \mathrm{M})$ for $60 \mathrm{~s}$ before being brushed with an LED light for $60 \mathrm{~s}$. After treatment, each disk was placed in a test tube and vortexed with $3 \mathrm{~mL}$ phosphate-buffered saline (PBS) and glass beads $(0.15 \mathrm{~mm}$ diameter, DAIHAN Scientific, Wonju, Korea) for $60 \mathrm{~s}$ to detach the bacteria. The solution containing detached bacteria was spread directly onto trypticase soy agar plates containing 1 $\mathrm{mg} / \mathrm{mL}$ yeast extract, $1 \mu \mathrm{g} / \mathrm{mL}$ menadione, $5 \mu \mathrm{g} /$ $\mathrm{mL}$ hemin, 5\% sheep blood (Hanil-Komed Co., Ltd., Seongnam, Korea), and 1.5\% Bacto agar (Becton, Dickinson and Company) using a spiral plate system (IUL, Barcelona, Spain). The plates were incubated under anaerobic conditions for $96 \mathrm{~h}$ at $37^{\circ} \mathrm{C}$. An automatic counter (IUL) was used to determine the number of colony-forming units (CFUs). The percentage of surviving bacteria was determined by counting the CFUs after incubation by dividing the number of CFUs on the treatment group disks with the number on the control group disks.

\section{Scanning electron microscopy}

Scanning electron microscopy (SEM) was used to visualize the changes in bacterial cell walls and observe the number of attached cells. The disks with attached bacteria were fixed in $2.5 \%$ glutaraldehyde for $2 \mathrm{~h}$ at room temperature. The fixed samples were washed $3 \times$ with PBS for 10 min each and dehydrated for $30 \mathrm{~min}$ in graded ethanol solutions $(30 \%, 50 \%$, $70 \%, 90 \%$, and $100 \%$ ). After critical point drying, samples were mounted on a stub, coated with gold, and observed with SEM. The surface of the disk was observed using variable pressure field emission SEM (SUPRA55VP, Carl Zeiss, Oberkochen, Germany).

\section{Statistical analysis}

The data were analyzed with a statistical program (SPSS $^{\text {TM }}$ 22.0, IBM Inc., Armonk, USA). Paired t-test and one-way analysis of variance with the Duncan correction were applied to assess differences in application. The level of significance was set at $P<0.05$.

\section{Results}

Table 2 presents the mean values of $\log \mathrm{CFU} / \mathrm{mL}$ and proportion of surviving bacteria according to static and dynamic culture methods. The mean values of $\log \mathrm{CFU} / \mathrm{mL}$ of biofilms in the dynamic method group were lower than those in the static group, but no significant difference was observed in the level of cell growth between the two methods. Regardless of culture method, the proportion of F. nucleatum was higher than that of $S$. gordonii, but not statistically significant. Fig. 1 shows SEM images of bacteria attached to the zirconia surface according to static and dynamic culture methods. No significant difference was observed in the SEM images between the two methods.

Table 3 shows the mean counts of viable bacteria and percentages of bacterial reduction according to static and dynamic culture methods and treatments.

Table 2. Quantitative analysis of biofilm formation with each method

\begin{tabular}{lcc}
\hline & \multicolumn{2}{c}{$\log \mathrm{CFU} / \mathrm{mL}$ (mean \pm SD) } \\
& Static method $(\%)$ & Dynamic method \\
\hline S.gordonii & $4.69 \pm 0.14(49.3)$ & $4.55 \pm 0.12(48.6)$ \\
F. nucleatum & $4.83 \pm 0.31(50.7)$ & $4.83 \pm 0.09(51.4)$ \\
Total cell count & $9.51 \pm 0.22(100)$ & $9.37 \pm 0.20(100)$ \\
\hline
\end{tabular}

$\mathrm{CFU}$, colony forming unit; SD, standard deviation. 

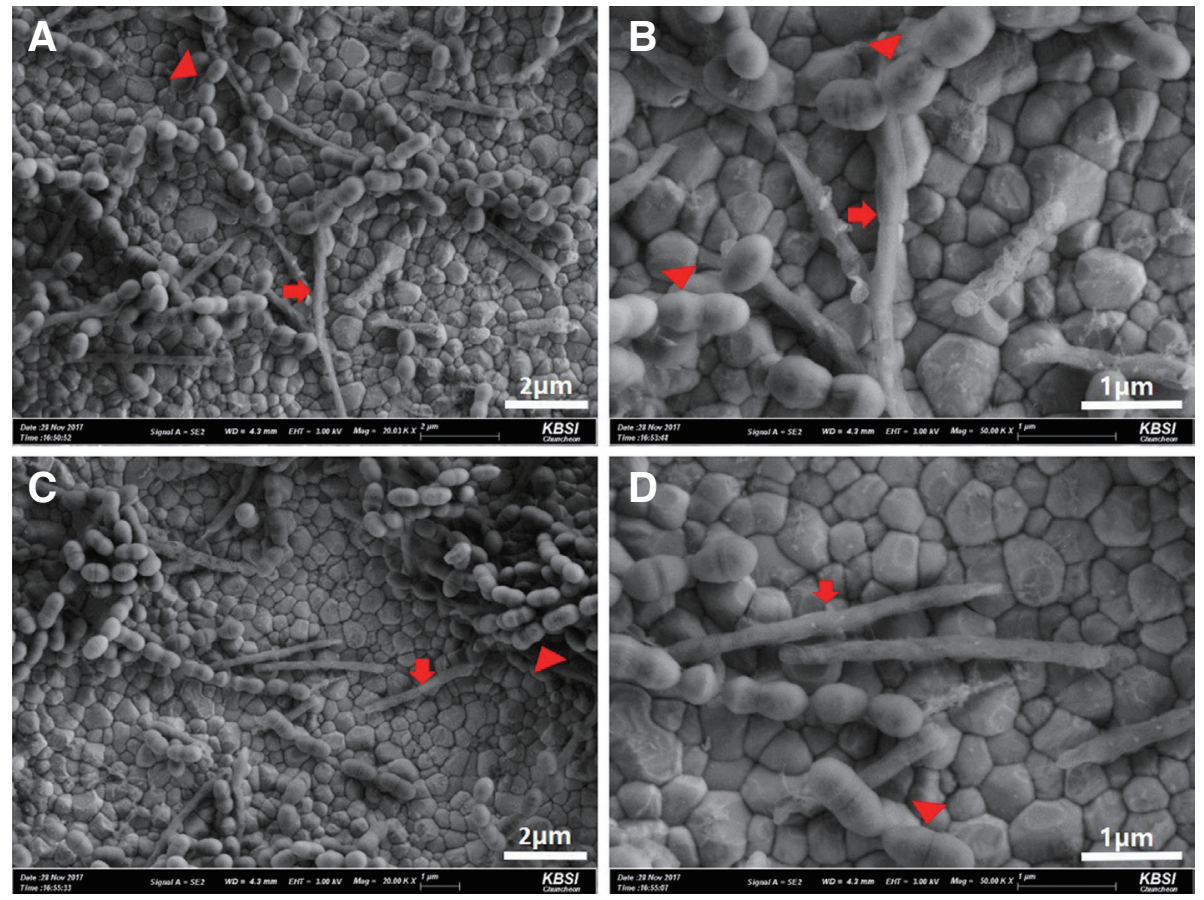

Fig. 1. Scanning electron microscopy images of attachment on zirconia surface according to culture method. (A, C) Biofilm in well plate (static method), (B, D) Biofilm in CDC biofilm reactor (dynamic method). The arrowheads indicate $S$. gordonii and the arrows indicate F. nucleatum. CDC: Center for Disease Control and Prevention.

Table 3. Counts of viable bacteria and percentages of bacterial reduction on the zirconia surface in different treatment groups

\begin{tabular}{ccccc}
\hline \multirow{2}{*}{ Group } & \multicolumn{2}{c}{ Log CFU $/ \mathrm{mL}($ mean $\pm \mathrm{SD})$} & \multicolumn{2}{c}{ Bacterial reduction (\%) } \\
& Static method & Dynamic method & Static method & Dynamic method \\
\hline Control & $5.10 \pm 0.08^{\mathrm{a}}$ & $5.01 \pm 0.09^{\mathrm{a}}$ & - & - \\
B & $4.66 \pm 0.33^{\mathrm{b}}$ & $4.68 \pm 0.28^{\mathrm{b}}$ & 54.3 & 47.5 \\
PDT & $4.64 \pm 0.29^{\mathrm{b}}$ & $4.38 \pm 0.22^{\mathrm{c}}$ & 59.4 & 74.6 \\
BL & $3.88 \pm 0.24^{\mathrm{c}}$ & $3.72 \pm 0.33^{\mathrm{d}}$ & 93.3 & 93.5 \\
BLE & $3.35 \pm 0.25^{\mathrm{d}}$ & $3.44 \pm 0.22^{\mathrm{d}}$ & 97.8 & 97.1 \\
\hline
\end{tabular}

CFU, colony-forming unit; SD, standard deviation; B, brush alone; PDT, photodynamic therapy; BL, brushing with a LED light; BLE, brushing with a LED light and erythrosine. Different superscript letters (a, b, c, d) indicate significant differences $(P<0.05)$.

Regardless of culture method, the control group showed significantly higher mean counts of viable bacteria than all of the experimental groups $(P<$ 0.05). Among the static method groups, $93.3 \%$ and $97.8 \%$ of bacteria were removed in the BL and BLE groups, respectively. Among the dynamic method groups, the BL and BLE groups showed bacterial reductions of $93.5 \%$ and $97.1 \%$, respectively, compared with the control groups. There were statistically significant differences among the treated groups, with the BLE group demonstrating the greatest antimicrobial effects for both culture methods.
Fig. 2 shows SEM images of S. gordonii and F. nucleatum attached to the zirconia surface by CDC biofilm reactor. In all SEM images, F. nucleatum and S. gordonii adhered to the zirconia surface of the disk, and the number of total bacteria decreased significantly in the $\mathrm{BL}$ and BLE groups compared to the other groups (Fig. 2A - 2E). The control and B groups showed intact bacterial morphology, however, damage to the bacterial cell wall was observed in the PDT, BL, and BLE groups (Fig. 2F - 2J). Especially, complete destruction of the cell wall and smaller amounts of bacterial attachment were observed in the BLE group. 

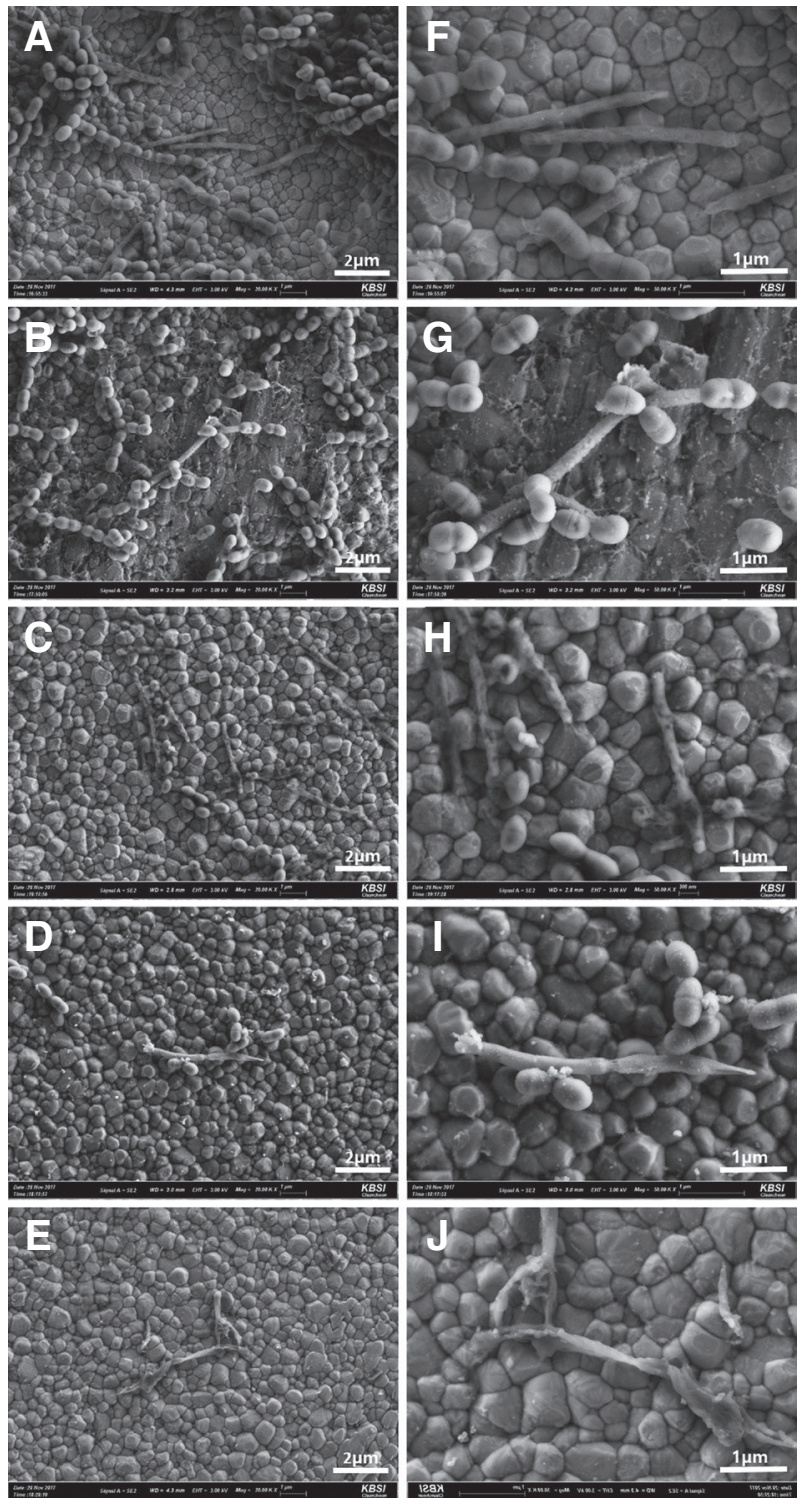

Fig. 2. Scanning electron microscopy images of $S$. gordonii and $F$. nucleatum attached to zirconia surface by $C D C$ biofilm reactor. $(A, F)$ control group; $(B, G)$ brush alone group; $(C, H)$ photodynamic therapy group; $(D, I)$ brushing with a LED light group; $(E, J)$ brushing with a LED light and erythrosine group.

CDC, Center for Disease Control and Prevention; LED, light-emitting diodes.

\section{Discussion}

This study was designed to evaluate the antimicrobial effects of LED toothbrushes on periodontitisassociated dental biofilm attached to zirconia surfaces by CDC biofilm reactor in vitro. We used $S$. gordonii and F. nucleatum to form a biofilm model by CDC biofilm reactor and 24-well plate. The CDC biofilm reactor was designed to create an environment similar to the saliva and gingival crevicular fluid in the oral cavity in vitro. ${ }^{27}$ We recently compared in vitro oral biofilms made by static and dynamic methods with F. nucleatum and P. gingivalis and discovered that the dynamic method (CDC biofilm reactor) formed looser biofilms containing fewer bacteria than the static method (well plate). ${ }^{28}$ However, both methods are useful for mimicking periodontitis-associated oral biofilms. In this study, the mean $\log \mathrm{CFU} / \mathrm{mL}$ of biofilms in the dynamic method group were lower than those in the static group, but no significant difference was observed in the level of cell growth between the two methods. Our results concur with the previous study, even though different periodontal bacteria were used in the two studies. F. nucleatum is the most abundant gram-negative anaerobic bacteria in biofilms from healthy gingiva and increases with periodontal disease progression. This study evaluated the antimicrobial effect of an LED toothbrush on the initial biofilm that could be formed on a zirconia abutment and crown, using $S$. gordonii and F. nucleatum to reproduce the conditions observed in peri-implant mucositis, an early peri-implant disease.

The incomplete removal of plaque around an implant may result in bacterial settlement, leading to peri-implant mucositis. The consequences give rise to peri-implantitis, leading to supportive marginal bone loss. Thus, cleaning the initial bacterial deposits plays an important role in the prevention of peri-implant disease. Several methods have been proposed for the initial treatment of peri-implant disease in clinical settings. ${ }^{29}$ A few conventional methods, including adjunctive antiseptic rinse, powered toothbrush, and irrigation, allow patients to control plaque; however, their efficacies are unproven, ${ }^{30}$ leading to the development of new instruments such as the LED toothbrush. The LED toothbrush may have dual action for dental biofilm; brushing is essential for oral hygiene to break the biofilm and LED light may be as effective as photodynamic therapy (PDT). Park et al. ${ }^{31}$ applied brushing with dentifrice to resorbable blasting media titanium disks incubated with $P$. 
gingivalis. The authors described significantly reduced bacterial adherence, but some bacteria remained in pits on the titanium. Schwartz et al. ${ }^{32}$ applied PDT to implants with peri-implant diseases and confirmed clinical efficacy within a short time. In the current study, regardless of culture method, the BL and BLE groups showed more than $90 \%$ bacterial reduction compared with the control groups, with the BLE group showing the greatest antimicrobial effects. The SEM images of the BL and BLE groups revealed significantly decreased numbers of total bacteria (Fig. 2A - 2E), and the PDT, BL, and BLE groups revealed damaged bacterial cell walls (Fig. 2F - 2J). Especially, the BLE group demonstrated complete destruction of the cell wall and smaller amounts of bacterial attachment; this effect was stronger in the presence of the photosensitizer erythrosine. SEM examination revealed morphological alterations of the bacteria in the BL and BLE groups, which seemed to be due to the antibacterial effects of the 2 blue LEDs $(465 \mathrm{~nm}, 64 \mathrm{~mW})$ and the commercial PDT kit. Song et al. ${ }^{33}$ compared the antimicrobial effects of blue light on periodontal pathogens in planktonic and biofilm conditions and noted that exposure to blue light for periodontal bacteria in the biofilm state is less effective than exposure in planktonic conditions. Habiboallah et al. ${ }^{34}$ studied the photodynamic sterilizing effect of visible light in the presence of erythrosine, a photosensitizer for gram-negative bacteria, and found that visible blue LED light (440 - $480 \mathrm{~nm}, 570 \mathrm{~mW}$ ) in conjugation with erythrosine significantly reduced bacterial viability. Thus, PDT alone may have limitations in the removal of bacteria and requires additional mechanical methods and photosensitizers. The wavelength of blue light used in this experiment failed to match the maximum absorption wavelength of erythrosine (525 nm), but contained the maximum absorption wavelength of erythrosine in the range of white light $(500-550 \mathrm{~nm}$, $22.7 \mathrm{~mW}$ ), which exhibits an antimicrobial effect on Streptococcus $s p p{ }^{35}$ The results of present study are in accordance with those previously reported.

A limitation of this study is that only two different bacterial strains were used for biofilm formation. Roder et al. ${ }^{36}$ suggested the possibility of including as many strains or natural environmental samples as possible for the development of biofilms with characteristics similar to those under natural conditions. Hence, further studies should consider the cultivation of several species of bacteria for biofilm formation.

\section{Conclusion}

Within the limitations of this study, the use of a blue LED toothbrush with erythrosine was shown to be more effective than conventional PDT for the removal of bacteria attached to zirconia surfaces. This method induced cell wall destruction of $S$. gordonii and F. nucleatum, the bacterial strains associated with early biofilm formation and early peri-implant disease. No significant difference was observed in biofilm formation between dynamic and static methods; both methods showed good reproducibility with biofilm formation on the zirconia disk surface. As tooth brushing is conventionally performed one to three times a day, an LED toothbrush would be useful patient-administered equipment for cleaning zirconia abutments exposed in the oral cavity. In addition, clinicians could apply LED with erythrosine after mechanical cleaning for the effective treatment of peri-implant mucositis.

\section{Acknowledgements}

This study was supported by the Scientific Research of Gangneung-Wonju National University Dental Hospital (SR1704). The LED toothbrush used in the experiment was provided by AinA (Daegu, South Korea). Zirconia discs were supplied by HASS Corporation (Gangneung, Korea). No potential conflict of interest relevant to this article was reported.

\section{ORCID}

Jong Hew Park https://orcid.org/0000-0001-8562-8080

Yong-Gun Kim https://orcid.org/0000-0002-2793-7667

Heung-Sik Um http://orcid.org/0000-0002-7986-1019

Si Young Lee http://orcid.org/0000-0001-8826-1413

Jae-Kwan Lee http://orcid.org/0000-0003-1710-1580

Beom-Seok Chang http://orcid.org/0000-0002-5280-3249 


\section{References}

1. Lang NP, Berglundh T. Periimplant diseases: where are we now?-Consensus of the Seventh European Workshop on Periodontology. J Clin Periodontol 2011;38 Suppl 11:178-81.

2. Sgolastra F, Petrucci A, Severino M, Gatto R, Monaco A. Periodontitis, implant loss and periimplantitis. A meta-analysis. Clin Oral Implants Res 2015;26:e8-e16.

3. Dalago HR, Schuldt Filho G, Rodrigues MA, Renvert S, Bianchini MA. Risk indicators for Peri-implantitis. A cross-sectional study with 916 implants. Clin Oral Implants Res 2017;28:144-50.

4. Serino G, Ström C. Peri-implantitis in partially edentulous patients: association with inadequate plaque control. Clin Oral Implants Res 2009;20:169-74.

5. Zhuang LF, Watt RM, Mattheos N, Si MS, Lai HC, Lang NP. Periodontal and peri-implant microbiota in patients with healthy and inflamed periodontal and peri-implant tissues. Clin Oral Implants Res 2016;27:13-21.

6. Ximénez-Fyvie LA, Haffajee AD, Socransky SS. Comparison of the microbiota of supra- and subgingival plaque in health and periodontitis. J Clin Periodontol 2000;27:648-57.

7. Kolenbrander PE, Andersen RN, Blehert DS, Egland PG, Foster JS, Palmer RJ Jr. Communication among oral bacteria. Microbiol Mol Biol Rev 2002;66:486-505.

8. Kolenbrander PE, Palmer RJ Jr, Periasamy S, Jakubovics NS. Oral multispecies biofilm development and the key role of cell-cell distance. Nat Rev Microbiol 2010;8:471-80.

9. Socransky SS, Haffajee AD, Cugini MA, Smith C, Kent RL Jr. Microbial complexes in subgingival plaque. J Clin Periodontol 1998;25:134-44.

10. Pérez-Chaparro PJ, Duarte PM, Shibli JA, Montenegro S, Lacerda Heluy S, Figueiredo LC, Faveri M, Feres M. The current weight of evidence of the microbiologic profile associated with peri-implantitis: A systematic review. J Periodontol 2016;87:1295304.

11. Scarano A, Piattelli M, Caputi S, Favero GA, Piat- telli A. Bacterial adhesion on commercially pure titanium and zirconium oxide disks: an in vivo human study. J Periodontol 2004;75:292-6.

12. Holst S, Blatz MB, Hegenbarth E, Wichmann M, Eitner S. Prosthodontic considerations for predictable single-implant esthetics in the anterior maxilla. J Oral Maxillofac Surg 2005;63:89-96.

13. Chen D, Wang N, Gao Y, Shao L, Deng B. A 3-dimensional finite element analysis of the restoration of the maxillary canine with a complex zirconia post system. J Prosthet Dent 2014;112:1406-15.

14. Heuer W, Elter C, Demling A, Neumann A, Suerbaum S, Hannig M, Heidenblut T, Bach FW, Stiesch-Scholz M. Analysis of early biofilm formation on oral implants in man. J Oral Rehabil 2007;34:377-82

15. Nascimento CD, Pita MS, Fernandes FHNC, Pedrazzi V, de Albuquerque Junior RF, Ribeiro RF. Bacterial adhesion on the titanium and zirconia abutment surfaces. Clin Oral Implants Res 2014;25:337-43.

16. Rimondini L, Farè $S$, Chiesa R, Pedeferri MP, Carrassi $\mathrm{A}$. The effect of composition, wettability and roughness of the substrate on in vivo early bacterial colonization of titanium. J Appl Biomater Biomech 2003;1:131-8.

17. Subramani K, Jung RE, Molenberg A, Hämmerle $\mathrm{CH}$. Biofilm on dental implants: a review of the literature. Int J Oral Maxillofac Implants 2009;24:61626.

18. Renvert S, Roos-Jansåker AM, Claffey N. Non-surgical treatment of peri-implant mucositis and periimplantitis: a literature review. J Clin Periodontol 2008;35:305-15.

19. Wainwright M. Photodynamic antimicrobial chemotherapy (PACT). J Antimicrob Chemother 1998;42:13-28.

20. Wood S, Metcalf D, Devine D, Robinson C. Erythrosine is a potential photosensitizer for the photodynamic therapy of oral plaque biofilms. J Antimicrob Chemother 2006;57:680-4.

21. Dougherty TJ, Gomer CJ, Henderson BW, Jori G, Kessel D, Korbelik M, Moan J, Peng Q. Photodynamic therapy. J Natl Cancer Inst 1998;90:889-905.

22. Bassetti M, Schär D, Wicki B, Eick S, Ramseier CA, 
Arweiler NB, Sculean A, Salvi GE. Anti-infective therapy of peri-implantitis with adjunctive local drug delivery or photodynamic therapy: 12-month outcomes of a randomized controlled clinical trial. Clin Oral Implants Res 2014;25:279-87.

23. Vohra F, Al-Rifaiy MQ, Lillywhite G, Abu Hassan MI, Javed F. Efficacy of mechanical debridement with adjunct antimicrobial photodynamic therapy for the management of peri-implant diseases: a systematic review. Photochem Photobiol Sci 2014;13:1160-8.

24. Wang H, Li W, Zhang D, Li W, Wang Z. Adjunctive photodynamic therapy improves the outcomes of peri-implantitis: a randomized controlled trial. Aust Dent J 2019;64:256-62.

25. Lee H, Kim YG, Um HS, Chang BS, Lee SY, Lee JK. Efficacy of an LED toothbrush on a Porphyromonas gingivalis biofilm on a sandblasted and acid-etched titanium surface: an in vitro study. J Periodontal Implant Sci 2018;48:164-73.

26. Blanc V, Isabal S, Sánchez MC, Llama-Palacios A, Herrera D, Sanz M, León R. Characterization and application of a flow system for in vitro multispecies oral biofilm formation. J Periodontal Res 2014;49:323-32.

27. Franklin MJ, Chang C, Akiyama T, Bothner B. New technologies for studying biofilms. Microbiol Spectr 2015;3. doi: 10.1128/microbiolspec.MB-0016-2014.

28. Song WS, Lee JK, Park SH, Um HS, Lee SY, Chang BS. Comparison of periodontitis-associated oral biofilm formation under dynamic and static conditions. J Periodontal Implant Sci 2017;47:219-30.

29. Louropoulou A, Slot DE, Van der Weijden F. The effects of mechanical instruments on contaminated titanium dental implant surfaces: a systematic re- view. Clin Oral Implants Res 2014;25:1149-60.

30. Salvi GE, Ramseier CA. Efficacy of patient-administered mechanical and/or chemical plaque control protocols in the management of peri-implant mucositis. A systematic review. J Clin Periodontol 2015;42 Suppl 16:S187-201.

31. Park JB, Koh M, Jang YJ, Choi BK, Kim KK, Ko Y. Removing bacteria from rough surface titanium discs with chlorhexidine and additional brushing with dentifrice. Gerodontology 2016;33:28-35.

32. Schwarz F, John G, Hegewald A, Becker J. Nonsurgical treatment of peri-implant mucositis and peri-implantitis at zirconia implants: a prospective case series. J Clin Periodontol 2015;42:783-8.

33. Song HH, Lee JK, Um HS, Chang BS, Lee SY, Lee MK. Phototoxic effect of blue light on the planktonic and biofilm state of anaerobic periodontal pathogens. J Periodontal Implant Sci 2013;43:72-8.

34. Habiboallah G, Mahdi Z, Mahbobeh NN, Mina ZJ, Sina F, Majid Z. Bactericidal effect of visible light in the presence of erythrosine on Porphyromonas gingivalis and Fusobacterium nucleatum compared with diode laser, an in vitro study. Laser Ther 2014;23:263-71.

35. Metcalf D, Robinson C, Devine D, Wood S. Enhancement of erythrosine-mediated photodynamic therapy of Streptococcus mutans biofilms by light fractionation. J Antimicrob Chemother 2006;58:190-2.

36. Røder HL, Raghupathi PK, Herschend J, Brejnrod A, Knøchel S, Sørensen SJ, Burmølle M. Interspecies interactions result in enhanced biofilm formation by co-cultures of bacteria isolated from a food processing environment. Food Microbiol 2015;51:18-24. 


\title{
지르코니아 표면에 부착된 바이오필름에 대한 LED 치솔의 항균효과
}

\author{
박종휴 ${ }^{1}$, 김용건 ${ }^{2}$, 엄흥식 ${ }^{1}$, 이시영 ${ }^{3}$, 이재관 $^{1 *}$, 장범석 $^{1 *}$ \\ ${ }^{1}$ 강릉원주대학교 치과대학 치주과학교실 및 구강과학연구소 \\ ${ }^{2}$ 경북대학교 치과대학 치주과학교실 \\ ${ }^{3}$ 강릉원주대학교 치과대학 미생물학 및 면역학교실
}

목적: 이번 연구의 목적은 정적인 방법과 동적인 방법으로 형성된 지르코니아 표면에 부착된 바이오필름에 대한 LED 칫 솔의 항균 효과를 평가하고자 하였다.

연구 재료 및 방법: 구강 바이오필름을 형성하기 위해 직경 $12 \mathrm{~mm}$, 두께 $2.5 \mathrm{~mm}$ 의 지르코니아 디스크를 24-well plate(정 적 방법)와 Center for Disease Control and Prevention (CDC) biofilm reactor (동적 방법)에 디스크를 넣어 바이오필름 을 형성하였다. 디스크는 아무 처치도 하지 않은 대조군, 상용화된 광역학(PDT) 키트, 치솔질(brushing) 단독, LED 치 솔군, LED 치솔과 에리스로신을 같이 적용한 군, 이렇게 5 개 그룹으로 구성하였다. 각 군별 처치 후, 개별 디스크를 시험 관에 넣고 60 초 동안 vortexing하여 세균을 분리한 후, 분리된 세균 용액을 선택 배지를 이용하여 살아있는 세균 수를 확 인한 후 실험 방법에 따른 항균 효과를 계측하였고, 주사전자현미경(SEM)을 통하여 세균의 형태 변화를 관찰하였다.

결과: 바이오필름의 형성과 구성비는 동적인 방법과 정적인 방법에 따른 차이는 관찰되지 않았다. 대조군과 실험군간에 세균의 생존률에 유의한 차이가 있었다 $(P<0.05)$. LED 치솔과 에리스로신을 같이 적용한 군에서 가장 높은 항균 효과 가 관찰되었다 $(P<0.05)$. 주사전자현미경 사진상에서 광역학치료군과, LED 치솔군, LED 치솔과 에리스로신을 같이 적용한 군은 세균의 형태 변화가 관찰되었으나, 대조군과 치솔질 단독 사용군에서는 세균의 형태 변화가 관찰되지 않았다. 결론: 이번 연구 결과 지르코니아 표면에 부착된 바이오필름을 효과적으로 제거하는 방법으로 LED 치솔과 에리스로신 을 같이 적용하는 것이 추천된다.

(구강회복응용과학지 2019;35(3): 160-9)

주요어: 바이로필름; 에리스로신; 임플란트주위 질환; 광역학치료; 치솔질

*교신저자: 이재관

(25457) 강원도 강릉시 죽헌길 7 강릉원주대학교 치과대학 치주과학교실

Tel: 033-640-3199 | Fax: 033-640-3103 | E-mail: periojk@gwnu.ac.kr *교신저자: 장범석

(25457) 강원도 강릉시 죽헌길 7 강릉원주대학교 치과대학 치주과학교실

Tel: 033-640-3188 | Fax: 033-640-3113 || E-mail: dentist@gwnu.ac.kr

접수일: 2019년 8월 27일 | 수정일: 2019년 8월 31일 || 채택일: 2019년 9월 1일 